\title{
PEMAHAMAN TENTANG MENEJEMEN BENCANA ALAM SISWA SEKOLAH MENENGAH PERTAMA
}

\author{
Sudrajat \\ Satriyo Wibowo \\ Email: sudrajat@uny.ac.id \\ Jurusan Pendidikan IPS FIS Universitas Negeri Yogyakarta
}

\begin{abstract}
Abstrak
Gempa bumi pada 27 Mei 2006 yang melanda DIY dan sekitarnya pukul 05.55 WIB memberikan gambaran bahwa gempa bumi dapat terjadi kapanpun tanpa diduga. Oleh karena penelitian tentang menejemen bencana pada sekolah siaga bencana menjadi penting untuk mengetahui: 1) pemahaman menejemen bencana siswa SMP di Kabupaten Bantul; 2) gambaran tentang pengetahuan siswa SMP di Kabupaten Bantul terhadap bencana gempa bumi. Penelitian menggunakan metode penelitian survai, populasi dari penelitian ini adalah siswa SMP Negeri 2 Imogiri Kabupaten Bantul. Jumlah populasi 363 siswa yang terdiri kelas VII sebanyak 123, kelas VIII 125, dan kelas XI 115. Sedangkan teknik pengambilan sample yaitu purposive sampling yaitu teknik sampel yang mempunyai tujuan khusus atau pertimbangan tertentu. Sampel dalam penelitian ini adalah 99 resonden dari seluruh siswa kelas IX. Teknik pengumpulan data dengan kuesioner yang terdiri dari 28 item pertanyaan. Teknik analisis data menggunakan statistik diskriptif untuk menjelaskan fenomena dengan menggunakan tabel frekuensi dalam bentuk persentase. Hasil penelitian menunjukkan bahwa: 1) pemahaman menejemen bencana responden sudah cukup baik dimana $72 \%$ responden mempunyai pemahaman tentang berbagai bencana alam dan kemungkinan bencana yang akan menimpa wilayah mereka; 2) Gambaran tentang menejemen bencana antara lain: responden mempunyai kesiapan dalam menghadapi bencana sudah sesuai dengan prosedur menghadapi bencana dengan menghindari korban sebanyak mungkin (77\%). Kesiapan ini ditunjukan dengan pengetahuan responden untuk mengikuti jalur evakuasi (88\%), menolong korban lain bila suasana sudah aman $(88 \%)$ serta memanfaatkan ruang perawatan di sekolah $(88 \%)$.
\end{abstract}

Kata Kunci: menejemen bencana, bencana alam, sekolah siaga bencana 


\begin{abstract}
Daerah Istimewa Yogyakarta (DIY) is one of the earthquakeprone areas in Indonesia. The risk of earthquakes in the province due to its location is in a meeting of the Eurasian plate and the IndoAustralia. Therefore, research on disaster management in disaster preparedness school becomes important to know: 1) understanding of disaster management junior high school students in Bantul; 2) an overview of the knowledge of junior high school students in Bantul to the earthquake. The study used survey research method that seeks to bring together know information about the characteristics, actions, opinions of a representative group of respondents considered the population. The population of this research is the students of SMP Negeri 2 Imogiri Bantul. Total population of 363 students consisting of 123 class VII, VIII class 125 and class XI 115. While the sampling technique is purposive sampling technique samples that have special purposes or specific considerations. The sample in this research is 99 respondent of all students of class IX. Data collection techniques with a questionnaire consisting of 28 items of questions. Data were analyzed using descriptive statistics to explain the phenomenon by using frequency tables in terms of percentage. The results showed that: 1) understanding of disaster management has been good enough respondents where $72 \%$ of respondents have an understanding of various natural disasters and possible disasters that will befall their region; 2) description of disaster management, among others: the respondents have disaster preparedness is in conformity with the procedures for disasters to avoid casualties as much as possible (77\%). Readiness is indicated by the respondents' knowledge to follow the evacuation route (88\%), helping other victims if the atmosphere is safe (88\%) as well as take advantage of the treatment room at school (88\%). Another point in favor of the respondents in the face of disaster preparedness is the availability of early warning facilities in the school, evacuation routes, treatment room, modules disaster, and disaster training conducted by school, BPBD, and other agencies concerned with disaster mitigation.
\end{abstract}

\title{
Keywords: disaster management, natural disaster, disaster preparedness schools
}




\section{Pendahuluan}

Indonesia merupakan salah satu negara yang terdiri atas beberapa pulau utama dan ribuan pulau kecil. Pulau utama di Indonesia antara lain: Sumatera, Jawa, Sulawesi, Kalimantan dan juga Irian atau Papua. Jika didasarkan pada angka statistik, wilayah territorial Indonesia didominasi lautan dengan perbandingan 4:1 dengan daratan. Meski demikian, jika semua pulau di Indonesia digabungkan menjadi satu, maka ia akan menempati urutan ke-15 negara terluas di dunia. Menilik letak geografisnya, maka wilayah Indonesia rawan terjadi bencana alam. Masih membekas dalam ingatan semua orang bagaimana bencana tsunami meluluhlantakkan Aceh, yang disusul gempa bumi pada tahun 2006 yang memporakporandakan wilayah Yogyakarta. Tanah air kita memang sunguh-sungguh dihadapkan pada resiko bencana alam yang meningkat dalam waktu yang bersamaan. Secara geografis Indonesia sangat rawan terjadi bencana alam baik yang berupa gempa, banjir, atau tsunami. Pertemuan lempeng Eurasia dan Indo-Australia berpotensi menyebabkan gempa tektonik, sedangkan curah hujan yang tinggi berpotensi rawan banjir mengingat banyaknya sungai di wilayah ini.

Daerah Istimewa Yogyakarta (DIY) merupakan salah satu daerah rawan bencana gempa bumi di Indonesia. Resiko gempa bumi di DIY disebabkan letaknya yang berada di pertemuan lempeng Eurasia dan Indo-Australia. Gempa bumi pada 27 Mei 2006 yang melanda DIY dan sekitarnya pukul 05.55 WIB memberikan gambaran bahwa gempa bumi dapat terjadi kapanpun tanpa diduga. Gempa bumi ini menewaskan 6.234 jiwa, 46.000 orang luka-luka, serta 139.000 rumah/bangunan hancur. Gempa ini hanya terjadi dalam waktu 57 detik, namun telah menimbulkan kerugian yang besar (Ella dan Usman, 2008: 74). 
Kondisi di atas menggambarkan bahwa masyarakat DIY harus selalu waspada terhadap ancaman gempa bumi. Hal itu dikarenakan hingga saat ini belum ada satupun teknologi yang mampu memprediksi kapan dan di mana gempa bumi akan terjadi secara akurat. Kejadian gempa bumi pada tahun 2006 merupakan contoh nyata bahwa gempa bumi dapat terjadi kapanpun dan di manapun. Sebagai negara dengan potensi dan riwayat bencana alam yang tinggi seharusnya Indonesia mempunyai pengalaman belajar dan mengatasi bencana. Badan Nasional Penang-gulangan Bencana (BNPB) mencatat bahwa setiap tahun Negara kita harus siap menghadapi bencana tidak kurang dari 500 bencana (BNPB: 2010). Hal yang dapat dipetik dari bencana alam yang dihadapi adalah bagaimana kita mempersepsikan terjadinya bencana alam dan bagaimanakah tingkat kerusakan yang mungkin timbul, serta bagaimanakah upaya dan respon untuk mengatasinya. Hal-hal tersebut perlu mendapatkan perhatian khususnya untuk daerahdaerah yang rawan bencana seperti Yogyakarta.

Dalam kehidupannya, manusia selalu dikelilingi oleh berbagai situasi yang dapat mengancam kesejateraan hidupnya. Situasi tersebut dapat dianggap sebagai situasi yang sangat berbahaya dan mengancam, dapat pula dianggap sebagai situasi yang tidak berbahaya. Penilaian terhadap berbagai situasi tersebut terkait dengan persepsi risiko terhadap bencana yang akan dihadapi. Hal ini penting untuk diketahui agar dapat ditelaah mengenai hal-hal yang dianggap sebagai risiko bencana. Kerugian akibat bencana bertambah apabila masyarakat belum mengerti upaya untuk mengurangi resiko bencana atau yang dikenal dengan mitigasi bencana. Mitigasi bencana merupakan upaya untuk mengurangi dampak bencana. Mitigasi ini terdiri dari mitigasi fisik (struktural) yaitu upaya mengurangi dampak 
bencana secara fisik dan mitigasi non fisik (nonstruktural) yaitu upaya mengurangi dampak bencana seccara non fisik yang diwujudkan dalam pendidikan mitigasi bencana (Radianta Triatmadja, 2010:141).

Di samping bencana alam, bencana sosial yang disebabkan oleh ulah manusia sendiri juga mengancam kelangsungan hidup masyarakat. Bencana sosial disebabkan oleh kelalaian manusia dalam melakukan menjemen resiko bencana. Bencana seperti kecelakaan dalam angkutan, kabut asap, banjir, tanah longsor, kebakaran hutan dan lahan, dan lain-lain merupakan contoh nyata dari buruknya menejemen dan mitigasi bencana. Pesawat terbang hilang atau tergelincir di landasan pacu, kapal-kapal ferry tenggelam atau rontok di lautan bebas, kereta api bertabrakan atau tergelincir satu kali seminggu, penumpang yang tak berkarcis berjatuhan dari atap yang berkarat. Tumpukan sampah yang berbau busuk dan tidak memperoleh izin telah mengubur kelompok pemulung yang tak berdaya, tanah longsor telah menghanyutkan rumah-rumah kardus ke anak-anak sungai, gempa bumi serta gelombang pasang telah menghancurkan kotakota serta desa-desa pantai. Kebakaran hutan di Sumatra telah menyesakkan nafas penduduk di daerah yang luas di Asia Tenggara. Semuanya itu memerlukan penanganan yang serius agar kehidupan yang dijalani oleh manusia semakin berkualitas dan terbebas dari ancaman bencana.

Strategi penanggulangan bencana akan dapat berjalan dengan efektif apabila penduduk mempunyai pemahaman yang memadai mengenai menejemen dan mitigasi bencana. Wilayah Kabupaten Bantul sebagai wilayah yang rawan dengan bencana khususnya gempa bumi membutuhkan menejemen bencana yang komprehensif agar resiko bencana dapat ditekan seminimal 
mungkin apabila bencana melanda kawasan tersebut. Oleh karena itu penelitian tentang pengetahuan menejemen bencana bagi siswa SMP di Kabupaten Bantul menjadi penting untuk dilakukan.

\section{Bencana Alam}

Bencana merupakan kejadian yang tidak biasa sulit direspon dan dampaknya bisa dirasakan oleh beberapa generasi. Bencana adalah peristiwa atau rangkaian peristiwa yang mengancam dan mengganggu kehidupan dan penghidupan masyarakat yang disebabkan, baik oleh faktor alam dan atau faktor nonalam maupun faktor manusia sehingga mengakibatkan timbulnya korban jiwa manusia, kerusakan lingkungan, kerugian harta benda, dan dampak psikologis. Definisi tersebut menyebutkan bahwa bencana disebabkan oleh faktor alam, non alam, dan manusia. Oleh karena itu, Undang-Undang Nomor 24 Tahun 2007 tersebut juga mendefinisikan mengenai bencana alam, bencana nonalam, dan bencana sosial.

Dilihat dari sifatnya, bencana dapat dikategorikan menjadi dua yaitu: bencana alam dan bencana akibat teknologi. Bencana dapat disebabkan oleh factor alam (natural disaster) atau oleh perbuatan manusia (man-made disaster). Faktor-faktor yang menyebabkan bencana antara lain: bahaya alam dan bahaya karena perbuatan manusia, kerentanan (vulnerability) masyarakat, dan kapasitas yang rendah dari komponen masyarakat. Menurut Badan Nasional Penang-gulangan Bencana (2010) jenis-jenis bencana antara lain:

1) Gempa Bumi merupakan peristiwa pelepasan energi yang menyebabkan dislokasi (pergeseran) pada bagian dalam bumi secara tiba-tiba. Mekanisme perusakan terjadi karena energi getaran gempa dirambatkan ke seluruh bagian bumi. 
Di permukaan bumi, getaran tersebut dapat menyebabkan kerusakan dan runtuhnya bangunan sehingga dapat menimbulkan korban jiwa. Getaran gempa juga dapat memicu terjadinya tanah longsor, runtuhan batuan, dan kerusakan tanah lainnya yang merusak permukiman penduduk. Gempa bumi juga menyebabkan bencana ikutan berupa, kecelakaan industri dan transportasi serta banjir akibat runtuhnya bendungan maupun tanggul penahan lainnya.

2) Tsunami diartikan sebagai gelombang laut dengan periode panjang yang ditimbulkan oleh gangguan impulsif dari dasar laut. Gangguan impulsif tersebut bisa berupa gempa bumi tektonik, erupsi vulkanik atau longsoran. Kecepatan tsunami yang naik ke daratan (run-up) berkurang menjadi sekitar 25-100 Km/jam dan ketinggian air.

3) Letusan Gunung Berapi adalah merupakan bagian dari aktivitas vulkanik yang dikenal dengan istilah "erupsi". Hampir semua kegiatan gunung api berkaitan dengan zona kegempaan aktif sebab berhubungan dengan batas lempeng. Pada batas lempeng inilah terjadi perubahan tekanan dan suhu yang sangat tinggi sehingga mampu melelehkan material sekitarnya yang merupakan cairan pijar (magma). Magma akan mengintrusi batuan atau tanah di sekitarnya melalui rekahan-rekahan mendekati permukaan bumi. Setiap gunung api memiliki karakteristik tersendiri jika ditinjau dari jenis muntahan atau produk yang dihasilkannya. Akan tetapi apapun jenis produk tersebut kegiatan letusan gunung api tetap membawa bencana bagi kehidupan. Bahaya letusan gunung api memiliki resiko merusak dan mematikan. 
4) Tanah Longsor merupakan salah satu jenis gerakan massa tanah atau batuan, ataupun percampuran keduanya, menuruni atau keluar lereng akibat dari terganggunya kestabilan tanah atau batuan penyusun lereng tersebut. Tanah longsor terjadi karena ada gangguan kestabilan pada tanah/batuan penyusun lereng.

5) Banjir dimana suatu daerah dalam keadaan tergenang oleh air dalam jumlah yang begitu besar. Sedangkan banjir bandang adalah banjir yang datang secara tiba-tiba yang disebabkan oleh karena tersumbatnya sungai maupun karena pengundulan hutan disepanjang sungai sehingga merusak rumah-rumah penduduk maupun menimbulkan korban jiwa.

6) Kekeringan adalah hubungan antara ketersediaan air yang jauh dibawah kebutuhan air baik untuk kebutuhan hidup, pertanian, kegiatan ekonomi dan lingkungan.

7) Angin Topan adalah pusaran angin kencang dengan kecepatan angin $120 \mathrm{~km} / \mathrm{jam}$ atau lebih yang sering terjadi di wilayah tropis diantara garis balik utara dan selatan, kecuali di daerah-daerah yang sangat berdekatan dengan khatulistiwa. Angin topan disebabkan oleh perbedaan tekanan dalam suatu sistem cuaca. Angin paling kencang yang terjadi di daerah tropis ini umumnya berpusar dengan radius ratusan kilometer di sekitar daerah sistem tekanan rendah yang ekstrem dengan kecepatan sekitar 20 Km/jam. Di Indonesia dikenal dengan sebutan angin badai.

8) Gelombang Pasang adalah gelombang air laut yang melebihi batas normal dan dapat menimbulkan bahaya baik di lautan, maupun di darat terutama daerah pinggir pantai. Umumnya gelombang pasang terjadi karena adanya angin 
kencang atau topan, perubahan cuaca yang sangat cepat, dan karena ada pengaruh dari gravitasi bulan maupun matahari. Kecepatan gelombang pasang sekitar 10-100 $\mathrm{Km} / \mathrm{jam}$. Gelombang pasang sangat berbahaya bagi kapalkapal yang sedang berlayar pada suatu wilayah yang dapat menenggelamkan kapal-kapal tersebut. Jika terjadi gelombang pasang di laut menyebabkan tersapunya daerah pinggir pantai atau disebut dengan abrasi.

9) Kebakaran adalah situasi dimana suatu tempat atau lahan atau bangunan dilanda api serta hasilnya menimbulkan kerugian. Sedangkan lahan dan hutan adalah semua kejadian bencana yang diakibatkan oleh kesalahan desain, pengoperasian, kelalaian dan kesengajaan manusia dalam penggunaan teknologi atau industri. Keadaan dimana lahan dan hutan dilanda api sehingga mengakibatkan kerusakan lahan dan hutan serta hasil-hasilnya dan menimbulkan kerugian.

10) Aksi teror atau sabotase adalah semua tindakan yang menyebabkan keresahan masyarakat, kerusakan bangunan, dan mengancam atau membahayakan jiwa seseorang atau banyak orang oleh seseorang atau golongan tertentu yang tidak bertanggung jawab. Aksi teror atau sabotase biasanya dilakukan dengan berbagai alasan dan berbagai jenis tindakan seperti pemboman suatu bangunan/tempat tertentu, penyerbuan tiba-tiba suatu wilayah,tempat, dan sebagainya. Aksi teror atau sabotase sangat sulit dideteksi atau diselidiki oleh pihak berwenang karena direncanakan seseorang atau golongan secara diam-diam dan rahasia.

11) Epidemi, Wabah dan Kejadian Luar Biasa merupakan ancaman yang diakibatkan oleh menyebarnya penyakit 
menular yang berjangkit di suatu daerah tertentu. Pada skala besar, epidemi atau wabah atau Kejadian Luar Biasa (KLB) dapat mengakibatkan meningkatnya jumlah penderita penyakit dan korban jiwa. Beberapa wabah penyakit yang pernah terjadi di Indonesia dan sampai sekarang masih harus terus diwaspadai antara lain demam berdarah, malaria, flu burung, anthraks, busung lapar dan HIV/AIDS. Wabah penyakit pada umumnya sangat sulit dibatasi penyebarannya, sehingga kejadian yang pada awalnya merupakan kejadian lokal dalam waktu singkat bisa menjadi bencana nasional yang banyak adalah suatu kondisi dimana terjadi huru-hara atau kerusuhan atau perang atau keadaan yang tidak aman di suatu daerah tertentu yang melibatkan lapisan masyarakat, golongan, suku, ataupun organisasi tertentu. enimbulkan korban jiwa. Kondisi lingkungan yang buruk, perubahan iklim, makanan dan pola hidup masyarakat yang salah merupakan beberapa faktor yang dapat memicu terjadinya bencana ini.

\section{Menejemen Bencana}

Manajemen bencana merupakan seluruh kegiatan yang meliputi aspek perencanaan dan penanggulangan bencana, pada sebelum, saat dan sesudah terjadi bencana yang dikenal sebagai siklus manajemen bencana. Tujuan menejemen bencana antara lain: (1) mencegah kehilangan jiwa; (2) mengurangi penderitaan manusia; (3) memberi informasi masyarakat dan pihak berwenang mengenai risiko, serta (4) mengurangi kerusakan infrastruktur utama, harta benda dan kehilangan sumber ekonomis (Agus Rahmat, 2015)

Penanganan bencana pada dasarnya di tujukan sebagai upaya untuk meredam dampaknya dan memperkecil korban jiwa, 
kerusakan dan kerugian yang diakibatkan oleh bencana. Jadi penanganan bencana bukan mencegah untuk terjadinya melainkan mencegah dampak atau akibat yang ditimbulkan oleh bencana dan memperkecil korban jiwa, kerugian secara ekonomis dan kerusakannya. Sudah sejak lama masyarakat tradisional bisa mengantisipasi terjadinya bencana karena mereka mampu melakukan prediksi, previsi dan preservasi secara langsung.

Manajemen bencana meliputi tahap-tahap sebagai berikut: 1. Sebelum bencana terjadi, meliputi langkah-langkah pencegahan, mitigasi, kesiapsiagaan dan kewaspadaan. 2. Pada waktu bencana sedang atau masih terjadi, meliputi langkahlangkah peringatan dini, penyelamatan, pengungsian dan pencarian korban. 3. Sesudah terjadinya bencana, meliputi langkah penyantunan dan pelayanan, konsolidasi, rehabilitasi, pelayanan lanjut, penyembuhan, rekonstruksi dan pemukiman kembali penduduk. Tahapan diatas dalam kenyataannya tidak dapat ditarik tegas antara tahapan satu ketahapan berikutnya. Demikian pula langkah - langkah yang diambil belum tentu dapat dilaksanakan secara berturut-turut dan runtut. Namun jelas bahwa manajemen bencana (disarter management) adalah suatu kegiatan atau rangkaian kegiatan yang menyeluruh, terpadu dan berlanjut yang merupakan siklus kegiatan.

\section{Metode Penelitian}

Penelitian menggunakan metode penelitian survey yaitu: jenis penelitian yang mengumpulkan informasi tentang karakteristik, tindakan, pendapat dari sekelompok responden yang representative yang dianggap sebagai populasi (Masri Singarimbun \& Sofian Efendi, 1982: 8). Dalam penelitian survai informasi dikumpulkan dari responden dengan menggunakan kuesioner yang dibatasi pada survai sampel yang dianggap mewakili 
populasi. Penelitian survai dengan menggunakan kuesioner sekarang ini jarang dipergunakan karena kebanyakan lebih banyak menggunakan polling (jajak pendapat) terutama di dalam hubungannya dengan pemilihan umum atau pemilihan kepala daerah. Jenis penelitian tersebut dipilih karena peneliti hanya berusaha mengumpulkan informasi sederhana tentang menejemen kebencanaan yang ada di sekolah siaga bencana. Kemudian informasi tersebut dapat dijadikan sebagai bahan untuk menjelaskan fenomena sosial yang terjadi di sekolah. Penjelasan tentang hal penting mengingat pendidikan kebencanaan yang masih belum mendapatkan kesempatan yang memadai.

Populasi penelitian adalah siswa SMP Negeri 2 Imogiri Kabupaten Bantul dengan jumlah populasi 365 siswa yang terdiri kelas VII sebanyak 123, kelas VIII 125, dan kelas XI 115. Teknik pengambilan sample yang dipergunakan yaitu purposive sampling yaitu teknik sampel yang mempunyai tujuan khusus atau pertimbangan tertentu (Sugiyono, 2008: 124). Sampel penelitian yang dipilih adalah kelas XI dengan pertimbangan bahwa kelas tersebut telah mendapat pelatihan tentang kebencanaan, sedangkan kelas lainnya belum mendapat pelatihan dan pembelajaran serupa.

Teknik pengumpulan data yang digunakan adalah kuesioner atau angket. Teknik angket dipergunakan untuk memperoleh data tentang pemahaman menejemen bencana siswa SMP Kabupaten Bantul. Pengukuran dalam kuesioner menggunakan skala model Likert (Rating Scale Likert), yaitu suatu instrumen pengukuran sikap yang terdiri dari satu daftar pertanyaan, dan responden harus membuat pertimbangan terhadap setiap pernyataan dan memilih respon dari tingkat setuju sampai tidak setuju (Oemar Hamalik, 2005:150). Kuesioner yang dipersiapkan oleh peneliti 
terdiri dari 28 item pertanyaan dimana pertanyaan tersebut dapat dikelompokkan dalam tiga bagian yaitu pertama bagian pemahaman bencana, sekolah siaga bencana, fasilitas sekolah siaga bencana, dan pelatihan-pelatihan kebencanaan.

Teknik analisis data yang digunakan adalah analisis deskriptif yang disajikan dalam bentuk persentase. Persentase digunakan untuk melihat karakteristik responden terhadap butir pernyataan yang digunakan. Suatu penelitian dilaksanakan didasarkan atas dasar keinginan untuk menjawab pertanyaanpertanyaan penelitian atau untuk mengungkapkan fenomena sosial atau fenomena alami tertentu. Untuk mencapai tujuan tersebut, peneliti harus terlebih dahulu merumuskan hipotesa, mengumpulkan data, memproses data, membuat analisa dan interpretasi. Analisa data adalah proses penyederhanaan data ke dalam bentuk yang lebih mudah dibaca dan diinterpretasikan (Efendi dan Manning, 1989: 263). Dalam proses pengolahan data hasil kuesioner biasanya digunakan statistik. Salah satu fungsi pokok statistik adalah menyederhanakan data penelitian yang amat besar jumlahnya menjadi informasi yang lebih sederhana dan lebih mudah dipahami. Selain itu, statistik dapat membandingkan hasil yang diperoleh dengan hasil yang terjadi secara kebetulan (by chance), sehingga memungkinkan peneliti untuk menguji apakah hubungan sistematis antara variabelvariabel yang diteliti, atau hanya terjadi secara kebetulan. Setelah data dianalisis dan informasi yang lebih sederhana diperoleh, hasil-hasilnya harus diinterpretasi untuk mencari makna dan implikasi yang lebih luas.

\section{Hasil Penelitian}

\section{Diskripsi Lokasi Penelitian}


SMP Negeri 2 Imogiri berlokasi di desa Sariharjo, Kecamatan Imogiri, Kabupaten Bantul tepatnya di Jalan Imogiri-Panggang Km. 3. Sekolah tersebut merupakan salah satu sekolah siaga bencana (SSB) di samping SMA Negeri Kretek, dan SD Negeri Parangtritis. Sebagai sekolah siaga bencana (SSB) maka berbagai fasilitas dan perlengkapan dan peralatan yang berkaitan dengan menejemen dan mitigasi bencana telah dimiliki. Beberapa peralatan dan perlengkapan yang telah dimiliki antara lain: modul kebencanaan, papan petunjuk, tower peringatan dini bencana, dan lain-lain.

Dalam bidang kurikuler kebencanaan juga harus dijadikan sebagai salah satu bahan pembelajaran baik terintegrasi dengan bidang pengajaran maupun dilakukan terpisah melalui berbagai kegiata. Di sekolah-sekolah tersebut materi kebencanaan baik tsunami, gempa bumi, maupun banjir diajarkan dengan cara diintegrasikan dengan materi pembelajaran yang lain yaitu: IPA, IPS, Agama, PKn, dan lainlain.

BPPD Bantul juga memberikan fasilitas kebencanaan seperti modul kebencanaan, alat-alat peraga, dan pelatihan penanggulangan bencana secara berkala dan berencana. Oleh karenanya pemilihan SMP Negeri 2 Imogiri sebagai tempat penelitian dianggap penting mengingat daerah imogiri yang termasuk daerah rawan bencana. Sungai Oya dan Opak, merupakan patahan yang membelah daerah Imogiri menjadi dua bagian yang akan sangat membahayakan apalagi kembali terjadi gempa tektonik seperti pada tahun 2006.

\section{Hasil Kuesioner}

Angket yang disusun tim peneliti terdiri dari 28 item pertanyaan yang secara garis besar dapat dikategorikan ke 
dalam 4 hal yaitu: pemahaman tentang bencana, kondisi sekolah siaga bencana, pelatihan kebencanaan, dan perilaku siswa ketika menghadapi bencana. Dari 100 angket yang disebarkan, hanya ada 1 angket yang tidak kembali dikarenakan ada 1 siswa yang tidak masuk pada saat pengambilan data. Angket diberikan kepada kelas IX dengan pertimbangan bahwa kelas tersebut telah sering terlibat dalam pelatihan kebencanaan. Mereka juga selalu mengikuti kegiatankegiatan kebencanaan yang diadakan oleh sekolah maupun instansi di luar sekolah.

a. Pemahaman Bencana

Pada umumnya siswa mempunyai pemahaman yang baik tentang bencana, khususnya becana alam gempa bumi. Namun sebagian besar responden kurang memahami bencana alam lainnya seperti: tsunami, banjir, dan gunung meletus. Pertanyaan tentang pemahaman bencana tertuang dalam item angket nomor: 1, 6, 10, 16, dan 28. Pemahaman siswa tentang jenis-jenis bencana dapat dilihat pada tabel sebagai berikut:

\begin{tabular}{|c|l|c|}
\hline No & \multicolumn{1}{|c|}{ Jenis Bencana } & Persentase \\
\hline 1 & Bencana alam & $81 \%$ \\
\hline 2 & Gempa bumi & $89 \%$ \\
\hline 3 & Tsunami & $52 \%$ \\
\hline 4 & Gunung Meletus & $59 \%$ \\
\hline \multicolumn{2}{|c|}{ Rata-rata } & $\mathbf{7 2 \%}$ \\
\hline
\end{tabular}

Sumber: Data primer

b. Keberadaan Sekolah Siaga Bencana (SSB)

Pada umumnya responden mempunyai apresiasi positif terhadap keberada-an sekolah mereka sebagai sekolah siaga bencana. Responden juga mengetahui bahwa sekolah siaga bencana mempunyai beberapa fasilitas yang menunjang 
seperti: petunjuk evakuasi, alat peringatan dini, ruang perawatan korban, dan panduan kebencanaan. Pertanyaan tentang sekolah siaga bencana tersebar dalam 18 item yaitu: nomor, 2, 3, 4, 5, 7, 8, 9, 11, 12, 19, 20, 21, 24, 26, 27. Pengetahun responden terhadap hal tersebut disajikan dalam tabel berikut ini.

\begin{tabular}{|c|l|c|}
\hline No & \multicolumn{1}{|c|}{ Pertanyaan } & Persentase \\
\hline 1 & SMP 2 Imogiri sebagai SSB & $89 \%$ \\
\hline 2 & Tujuan SSB & $81 \%$ \\
\hline 3 & Tanggap bencana & $86 \%$ \\
\hline 4 & Petunjuk jalur evakuasi ketika bencana & $91 \%$ \\
\hline 5 & Alat peringatan dini bencana di sekolah & $79 \%$ \\
\hline 6 & $\begin{array}{l}\text { Pelibatan orang tua dalam menejemen } \\
\text { bencana }\end{array}$ & $58 \%$ \\
\hline 7 & Panduan tentang bencana di sekolah & $89 \%$ \\
\hline 8 & Fasilitas perawatan korban di sekolah & $88 \%$ \\
\hline 9 & Modul kebencanaan di sekolah & $73 \%$ \\
\hline \multicolumn{2}{|c}{ Rerata } & $\mathbf{8 2} \%$ \\
\hline
\end{tabular}

Sumber: Data primer

c. Pelatihan Kebencanaan

Pada umumnya siswa berpendapat bahwa pelatihan kebencanaan yang diadakan oleh sekolah dianggap penting sebagai salah satu bentuk kegiatan mitigasi dan menejemen bencana. Mereka juga sangat setuju dengan adanya pelatihanpelatihan tersebut karena dianggap sangat berguna untuk persiapan menghadapi bencana yang datang sewaktu-waktu. Pertanyaan tentang pelatihan kebencanaan ditunjukkan dengan item nomor: 4, 5, 7, 8, 20, dan 21 .

\begin{tabular}{|c|c|c|}
\hline No & Pertanyaan & Persentas \\
& & e \\
\hline
\end{tabular}




\begin{tabular}{|c|l|c|}
\hline 1 & Memasukkan bencana dalam pelajaran & $72 \%$ \\
\hline 2 & $\begin{array}{l}\text { Frekuensi mengikuti pelatihan kebencanaan di } \\
\text { sekolah }\end{array}$ & $89 \%$ \\
\hline 3 & Rutinitas pelatihan kebencanaan di sekolah & $82 \%$ \\
\hline 4 & Pelatihan dari luar sekolah & $79 \%$ \\
\hline 5 & Pelatihan dari dalam sekolah & $64 \%$ \\
\hline \multicolumn{2}{|r}{ Rerata } & $\mathbf{7 7 \%}$ \\
\hline
\end{tabular}

Sumber: Data primer

d. Sikap Menghadapi Bencana

Pada umumnya reesponden sudah mempunyai pemahaman yang memadai tentang menejemen bencana. Namun ketika ditanyakan bagaimanakah sikap dan tindakan yang benar ketika terjadi bencana, responden menunjukkan sikap yang tidak sesuai dengan pengetahuan mereka yaitu: takut, panik dan lari. Pertanyaan tentang sikap dalam menghadapi bencana ditunjukkan oleh item nomor: 13, 14, 15, 17, 23. Hasil angket dari pertanyaan-pertanyaan tersebut dapat digambarkan dengan tabel berikut:

\begin{tabular}{|c|l|c|}
\hline No & \multicolumn{1}{|c|}{ Diskripsi Pertanyaan } & Persentase \\
\hline 1 & Takut dan panik & $76 \%$ \\
\hline 2 & Berlari ke segala penjuru & $66 \%$ \\
\hline 3 & Tenang dan tidak panik & $66 \%$ \\
\hline 4 & Lari menuju ke tempat yang ditentukan & $88 \%$ \\
\hline 5 & Menolong teman ketika suasana aman & $88 \%$ \\
\hline & Rerata & $77 \%$ \\
\hline
\end{tabular}

Sumber: Data primer

Pemahaman tentang bencana merupakan aspek yang penting bagi siswa karena pemahaman dan pengetahuan yang memadai tentang bencana akan memberikan referensi yang benar juga dalam bersikap dan bertindak. Pemahaman yang memadai 
juga akan memberikan efek reduksi korban bencana, khususnya korban nyawa manusia. Hal ini sejalan dengan gagasan Garvin \& Roberto (2001: 108). yang menyatakan bahwa pengalaman pribadi, ingatan, dan faktor lainnya mempengaruhi cara masyarakat mempersepsikan resiko dan dapat mengacuhkan probababilitas atau peluang terjadinya dampak. Masyarakat Imogiri mempunyai pengalaman traumatik dengan bencana alam berupa gempa bumi yang terjadi pada tanggal 27 Mei 2006. Patahan berupa sungai Oya dan Opak yang memanjang di Imogiri memberikan getaran yang sangat kuat hingga merusak bangunan (rumah penduduk) dan fasilitas umum lainnya. Hal inilah barangkali yang menyebabkan pemahaman masyarakat Imogiri terhadap bencana alam gempa bumi sangat baik. Hal ini berbeda dengan jenis bencana lainnya seperti erupsi maupun tsunami yang belum pernah mereka alami.

Diantara jenis-jenis bencana yang dipahami dengan baik oleh siswa adalah bencana gempa bumi, sedangkan jenis bencana lain kurang dipahami (gunung meletus: 59\%, dan tsunami: 52\%). Dilihat dari persentasenya, maka lebih dari 50\% siswa mempunyai pemahaman yang baik mengenai bencana. Pemahaman mereka ini diperoleh melalui pelajaran di sekolah, modul kebencanaan, dan pelatihan-pelatihan yang diadakan oleh sekolah dan lembaga lain. Di samping itu faktor keterbukaan informasi terutama media massa berupa televisi dan surat kabar mempunyai andil yang sangat besar dalam memberikan informasi dan pengetahuan terhadap bencana alam dan mitigasi yang harus dilakukan.

Persepsi mengenai sekolah siaga bencana juga menunjukkan respon yang sangat baik, dimana secara umum siswa mengetahui bahwa sekolah mereka merupakan sekolah siaga bencana (89\%). Mereka juga menganggap bahwa sekolah 
siaga bencana mempunyai peranan yang signifikan dalam mengurangi dampak resiko bencana (89\%). Bagi siswa pembentukan sekolah siaga bencana di kabupaten Bantul yang terdiri dari tiga sekolah merupakan langkah strategis untuk melakukan upaya pendidikan lingkungan sekaligus pendidikan kebencanaan meskipun materinya diintegrasikan dengan mata pelajaran lain seperti IPS, dan IPA. Sebagian besar siswa (72\%) siswa menyatakan sangat setuju apabila materi tentang bencana dijadikan sebagai mata pelajaran baru dengan nama pendidikan kebencanaan. Mereka menganggap hal tersebut perlu karena mereka tinggal di daerah rawan bencana sehingga mempunyai pemahaman yang baik tentang bencana alam.

Fasilitas yang dimiliki oleh sekolah dirasakan masih kurang oleh siswa (47\%). Hal ini bisa jadi disebabkan adanya kesenjangan antara alat peraga, atau alat lainnya dengan jumlah siswa. Sekolah sudah dilengkapi dengan 3 buah alat peringatan dini bencana, plang jalur evakuasi, modul bencana, dan alat komunikasi. Mereka berpendapat bahwa pemerintah diharapkan memberikan atau menyediakan alat peringatan dini bencana, bukan hanya di sekolah tetapi juga di berbagai tempat agar semua penduduk dapat mengetahui apabila bencana alam datang.Mereka juga mengharapkan agar alat-alat tersebut dikontrol apakah masih dapat berfungsi dengan baik atau tidak.

Pelatihan kebencanaan juga dianggap penting dimana 89\% responden menyatakan sangat setuju apabila kegiatan pelatihan tersebut diadakan rutin. Namun para siswa berharap agar pelatihan yang dilaksanakan di sekolah mendatangkan instruktur dari luar sekolah.Simulai tentang kebencanaan juga dianggap penting sehingga dianggap penting untuk dilaksanakan. Simulasi bencana gempa, tsunami, dan erupasi gunung Merapi perlu 
disimulasikan agar ketika bencana tersebut betul-betul datang, mereka tidak lagi panic dan bingung.

Hal terakhir yang ditanyakan adalah sikap dan perilaku siswa ketika terjadi bencana. Sebanyak $76 \%$ responden menyatakan panik dan takut apabila terjadi bencana alam. Sikap ini barangkali berangkat dari pengalaman mereka ketika terjadi bencana beberapa waktu yang lalu seperti bencana gempa bumi 2006. Namun meskipun menyatakan panik dan takut, mereka menyatakan sangat setuju untuk tidak berlari ke segala arah (83\%). Mereka menyatakan sangat setuju untuk lari dan berkumpul di tempat tertentu. Hal ini barangkali merupakan dampak dari berbagai pelatihan dan simulasi bencana sehingga mereka sudah mempunyai pemahaman yang memadai tentang perilaku dan sikap yang sesuai ketika terjadi bencana.

\section{Simpulan}

Pada umumnya responden (siswa) mempunyai pemahaman yang memadai tentang becana, khususnya becana alam gempa bumi, namun sebagian besar kurang mengetahui bencana alam tsunami dan gunung meletus. Responden mempunyai apresiasi positif terhadap sekolah sebagai sekolah siaga bencana. Mereka juga mengetahui bahwa sebagai sekolah siaga bencana, sekolah mempunyai beberapa fasilitas seperti: petunjuk evakuasi, alat peringatan dini, ruang perawatan korban, dan panduan kebencanaan. Persepsi mengenai sekolah siaga bencana juga menunjukkan respon yang sangat baik, dimana secara umum siswa mengetahui bahwa sekolah mereka merupakan sekolah siaga bencana $(89 \%)$.

Responden menganggap bahwa sekolah siaga bencana mempunyai peranan yang signifikan dalam mengurangi dampak 
resiko bencana (89\%). Fasilitas yang dimiliki oleh sekolah dirasakan masih kurang oleh siswa (47\%). Hal ini bisa jadi disebabkan adanya kesenjangan antara alat peraga, atau alat lainnya dengan jumlah siswa. Sekolah sudah dilengkapi dengan 3 buah alat peringatan dini bencana, plang jalur evakuasi, modul bencana, dan alat komunikasi. Mereka berpendapat bahwa pemerintah diharapkan memberikan atau menyediakan alat peringatan dini bencana, bukan hanya di sekolah tetapi juga di berbagai tempat agar semua penduduk dapat mengetahui apabila bencana alam datang. Mereka juga mengharapkan agar alat-alat tersebut dikontrol apakah masih dapat berfungsi dengan baik atau tidak.

\section{Daftar Pustaka}

Agus Rahmat, (2015). Menejemen Bencana. Tersedia dalam http://web.iaincirebon. ac.id/ebook/moon/SocialWelfare/Disaster/Manajemen\%20dan \%20mitigasi.pdf

Bimo Walgito. (2004). Pengantar Psikologi Umum. Yogyakarta: Andi Offset.

Dadang Sungkawa. (2011). Letak Indonesia (Jurnal). http://file.upi.edu/Direktori/ FPIPS/JUR._PEND._GEOGRAFI/195502101980021DADANG SUNGKAWA/letak_Indonesia.pdf. diunduh pada tanggal 12 Desember 2012 jam 07.25 WIB.

DEPKOMINFO. (2008). Memahami Bencana: Informasi Tindakan Masyarakat Mengurangi Resiko Bencana. Jakarta: Badan Informasi Publik Pusat.

Ella Yulaelawati dan Usman Syihab. (2008). Mencerdasi Bencana Banjir. Jakarta: PT. Grasindo.

Garvin, David A., and Michael A. Roberto. What You Don't Know About Making Decisions. Harvard Business Review 79, no. 8 (September 2001): 108-116. 
Hadi Purnomo dan Ronny Sugiantoro. (2010). Manajemen Bencana: Respons dan Tindakan terhadap Bencana. Jakarta: Media Pressindo.

Masri Singarimbun \& Sofian Efendi (1982). Metode Penelitian Survey. Yogyakarta: Tiara Wacana.

Nanang Martono. (2010). Metode Penelitian Kuantitatif. Jakarta: Rajawali Pers.

O. Lange; M. Ivanova \& N. Lebedeva. (1991). Geologi Umum (alih bahasa: Eric Jayaporhas Silitonga). Jakarta: Gaya Media Pratama.

Oemar Hamalik (2008). Proses Belajar Mengajar. Jakarta: Boemi Aksara.

Radianta Triatmadja. (2010). Tsunami: Kejadian, Penjalaran, Daya Rusak, dan Mitigasinya. Yogyakarta: Gajah Mada University Press.

S. Arie Prambodo. (2005). Panduan Praktis Menghadapi Bencana. Yogyakarta: Penerbit Kanisius.

Sugiyono (2013). Metodologi Penelitian Pendidikan: Kuantitatif, Kualitatif, dan $R \& D$. Bandung: Bumi Aksara.

Undang-undang No. 24 tahun 2007 tentang Penanggulangan Bencana.

Wasis Suprapto, dkk. (2011). Penerapan Program Pembelajaran Mitigasi Bencana Bagi Siswa SMP (Studi Kasus Di SMPN 2 Sanden), Pelita, VI, 2. Hlm. 51-65. 